\title{
Report on the scientific seminar in Obrzycko (27-28 June 2018)
}

DOI: $10.14746 /$ bhw.2018.38.17

A scientific seminar devoted to the research workshop of a contemporary historian of upbringing in Obrzycko is organised annually at the end of the academic year by the Department of History of Upbringing at the Faculty of Educational Studies of the Adam Mickiewicz University in Poznań under the direction of Prof. Wiesław Jamrożek, PhD. Traditionally, the meeting is guided by one leading theme, around which lectures are delivered and disputes are held. This year, a two-day seminar was held between 27 and 28 June 2018, with the theme of the event being "History of education in pedagogical journalism". The seminar was attended by both employees of the Department of History of Upbringing at the Faculty of Educational Studies of the Adam Mickiewicz University and invited guests from research centres all over Poland.

The official opening of the seminar took place on 27 June at 3 p.m. Prof. Wiesław Jamrożek, PhD, officially welcomed the guests and opened the meeting. Next, the invited guests and employees of the Department of History of Upbringing at the Faculty of Educational Studies of the Adam Mickiewicz University in Poznań took the floor, presenting their achievements and plans for the coming years, mentioning already completed research grants, as well as those just obtained.

Prof. Justyna Gulczyńska, PhD (UAM) was the first to present a lecture about "Polish journals on the history of education". She presented various nationwide scientific journals, including some of the oldest journals devoted to the history of education: Przeglad Historyczno-Oświatowy [Historical-Educational Review], published from 1947 to the present day, and the Rozprawy z Dziejów Oświaty [Treatises from the History of Education], published with breaks from 1958 to the present day. Taking advantage of the unique opportunity offered by his being present in the room, the editor-in-chief of one of the above-mentioned journals - Prof. Witold Chmielewski, PhD (Ignatianum Academy) took the floor and focused on the history of Przeglad Historyczno-Oświatowy. Professor Chmielewski presented the history of the periodical and pointed out that from the very beginning, the following departments had been designated in the periodical: treatises, materials, reviews (which still function at $\mathrm{PHO}$ with minor changes).

After a short break, Krzysztof Ratajczak, PhD (UAM) presented a paper entitled: "Indexing periodicals". The participants of the seminar had the opportunity to learn more about databases and the evaluation of scientific journals. Dr Ratajczak focused on the issue of the number of citations according to the Web of Since and the H Index. No less important an issue raised by the speaker was the position of humanities periodical in global databases, which caused a lively dispute among the participants of the seminar.

Tomasz Fetzki, PhD (representing the Lusatian University in Żary) presented a paper entitled "The periodical as a source of research on the birth of Polish special needs education", which concluded the first day of the scientific seminar in Obrzycko. Dr Fetzki pointed out, on the one hand, the lack of thorough scientific research into the beginnings 
of Polish special education, and on the other hand, the great need to deal with its history based, for example, on the source of articles from periodicals from the turn of the 19th and 20th centuries. However, as he himself pointed out, this is a laborious work requiring the collection of residual information dispersed in dailies and periodicals of the period.

The scientific seminar provides an opportunity to exchange experiences and different perspectives on a given issue. This was the case here, too. After the presentations, the participants of the seminar, under the direction of Prof. J. Gulczyńska (UAM) and Prof. W. Jamrożek (UAM) discussed periodicals as a historical source, and also spoke about contemporary periodical related to the history of upbringing and their place in the present world of science. Consideration was given both to individual presentations, where valuable comments were made both to the speakers and to the participants, and took on a more universalist form from which all participants could benefit. For example, Prof. Edyta Głowacka-Sobiech, PhD (Adam Mickiewicz University) drew attention to the exceptional role of women in the formation of special education in Polish territories and in Poland. On the other hand, Krzysztof Ratajczak, PhD, pointed to the multi-faceted character of scores in contemporary scientific journals, especially those related to the history of education.

The next item on the agenda was the promotion of books by the employees of the Department of History of Upbringing at the Faculty of Educational Studies of the Adam Mickiewicz University, as well as the latest publications on the history of upbringing (published in 2017 and 2018). The presentation was made by Mikołaj Brenk, PhD (UAM) and Konrad Nowak-Kluczyński, PhD (UAM). From among many publications, they chose the following positions: Wielkopolska $i$ Wielkopolanie $w$ dziejach polskiej edukacji [Wielkopolska and its citizens in the history of Polish education] (edited by Edyta Głowacka-Sobiech and Katarzyna Kabacińska-Łuczak), zbiór źródet do dziejów wychowania XVI-XVII oraz XVIII wieku [A collection of sources for the history of the 16-17th and 18th-century upbringing] by Dorota Żołądź-Strzelczyk and Małgorzata M. Kowalczyk, the publication Zachować dla przyszłości. Sprawy szkolnictwa i oświaty w przekazie prasowym XX i pierwszych lat XXI wieku [Preserve for the future. Educational issues in the press of the 20th and first years of the 21st century] (edited by Iwonna Michalska and Grzegorz Michalski), the book Obrazki do dziejów oświaty w Wielkopolsce Wschodniej [Pictures from the History of Education in Eastern Wielkopolska] by Piotr Gołdyn, the book Dojrzałość $i$ dojrzewanie [Maturity and adolescence] by Ewa Kubiak-Szymborska, Dariusz Zając, Ewa Krause, Monika Nawrot-Borowska, a study entitled Pedagogika harcerskiego wychowania [The pedagogy of scouting upbringing] by Bogusław Śliwerski, and many others. The first day of the meeting ended with a fireside integration meeting of the participants.

On the second day of the seminar, the participants continued their discussions on the issues discussed on the first day of the meeting. In addition, the seminar "The research workshop of the contemporary historian of upbringing" offered great value and the idea of continuation of meetings in subsequent years was supported. 